\title{
Historein
}

Vol $10(2010)$

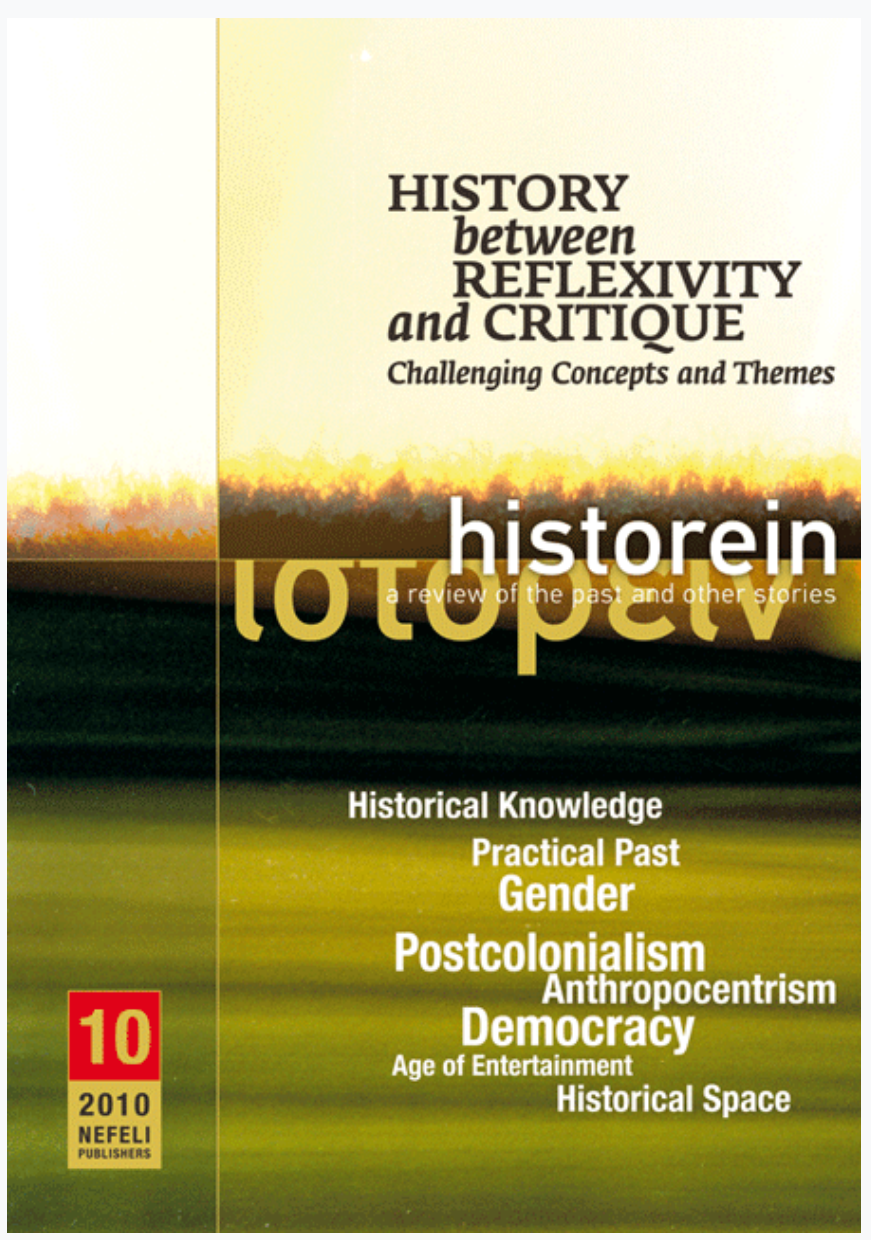

\section{Gender History and the Transformation of the Poetics of Historical Knowledge}

Pothiti Hantzaroula

doi: $10.12681 /$ historein.6

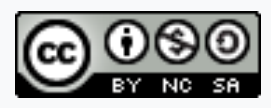

This work is licensed under a Creative Commons Attribution-NonCommercialShareAlike 4.0.

To cite this article:

Hantzaroula, P. (2011). Gender History and the Transformation of the Poetics of Historical Knowledge. Historein, 10, 48-70. https://doi.org/10.12681/historein.6 


\section{Gender History and}

the Transformation

of the Poetics

of Historical

Knowledge
Pothiti Hantzaroula

University of the Aegean
The key aspects of historical thinking and practice which are essential to an understanding of how historians come to terms with the past consist of, according to Alan Munslow, the epistemological model on which knowledge of the past depends, the role of referentiality in constituting the discourse of history, the literary procedures by which a discourse gives itself the status of science, and the deployment of theory and concept in creating meaning about the past. ${ }^{1}$ Jacques Rancière uses the term poetics of knowledge to refer to the epistemological break of historical discourse. The poetics of knowledge is the study of the rules according to which knowledge is written and read, and is constituted as a specific genre of discourse. ${ }^{2}$

Feminist historiography has intervened critically in the presuppositions that organise the past and constitute points of conflict among historians. These presumptions comprise of positivism, historical writing purporting to be an impersonal observer's objective account of historical actors and agents, a conception of time according to which the world must be seen as a historically developing entity, categories of periodisation that reflect a linear conception of time, and the archive as the foundation to find truth in the past. ${ }^{3}$ Both empirical and constructivist epistemologies share the belief in the possibility of knowing the past, in the referentiality of sources and the separation of the historian from his/her object of inquiry. The ontology of individuality and the intentionality of actors in historicism is substituted in the constructivist approach by the discovery of structural relations of 
historical change and their different kinds of determinations (class, national, race, gender, etc.) that function as explanatory factors. ${ }^{4}$

The article attempts to undertake an epistemological inquiry in respect to feminist historiography, that is, to interrogate the very operation in which historical knowledge is grasped in feminist historical writing. ${ }^{5}$ It focuses on theoretical and methodological approaches of gender history, and more extensively of feminist theory, that transformed or point to a radical transformation of historical study and writing. As Joan Scott argues, "Feminism's historical specificity comes from the fact that it works within and against whatever are the prevailing foundational assumptions of its time."6 Gender history cannot be approached as a homogeneous field because some of its expressions are permeated by the same assumptions and by the same disputes that preponderate in historiography. It can best be viewed as a form of critique, a disruptive, disorienting and, at times, destructive enterprise of knowledge. The article argues that the rethinking of history's constitutive premises undertaken by gender history consists of the investigation of history as a gendered enterprise and of the exploration of the gendered subjectivity of the historian, conceptualisations of the archive, challenges posed to conventional historiography by historical writing, the interrogation of politicised identity and of "women" as a historically variable category. Finally, it considers the history of science, the history of the body and the history of sexuality as the fields that have most challenged the knowledge that organises our perceptions of "nature" and have called into question positivist history.

\section{The historian's subjectivity and the concept of the archive}

Placing the historian at the centre of their analysis, Bonnie Smith, Joan Scott, Ilaria Porciani and Luisa Passerini have shown history to be a kind of patrimony: the term corresponds to the fact that for a long time historiography has been appropriated by men. They all agree that gender was a constitutive element of academic history, and gender metaphors were important to its formation and to the construction of explanatory schemes. ${ }^{8}$

Gendering the historical narrative opened up illuminating insights into the gender metaphors and dichotomies that permeate the historical imagination. Regina Schulte explores the creation of myths in historical narratives by presenting the example of the royal couple. The metamorphosis of the royal couple into a middle-class family signals a shift in the representation of monarchy in historical discourse. Marie Antoinette appeared as a middle-class mother and wife who lived the drama of separation from her children and husband. ${ }^{9}$ The image of the queen before the revolutionary tribunal incorporated the queen into French national history and at the same time rehabilitated the institution of the family that had been harmed during the revolution.

For Luisa Passerini, an area of historical meaning that needs to be recognised and historicised refers to the subjectivity of the historian. ${ }^{10}$ While history at the time of its formation as an academ- 
ic discipline was to a great extent a family issue, since all the members of the family participated in different stages of research and writing, the place of the author was exclusively preserved for males. ${ }^{11}$ The connection between historical rationality and gender led to the establishment of the historical profession as a male enterprise. On the one hand, the search for objectivity was perceived as appropriate for masculine identity while a new pedagogical role was attributed to the methods of historical study (namely, seminar and archival research) in the improvement of men. ${ }^{12}$ On the other hand, the scientific character of history was based on the capacity of men to leave aside their gender and class, their political stance as well as their passions and interests. The claim to objectivity was based on the capacity of the white male to act as universal signifier while the female was identified with partiality and particularity. Luisa Passerini and Polymeris Voglis, in their edited collection Gender in the Production of History, set as their task to show that the claim to objectivity was based on the invisibility of the historian as an author. They argue that "the more hidden in the reconstruction of the past the historian was, the more objective and universal his analysis was". ${ }^{13}$

The introduction of the concept of subjectivity and the methodological choice that puts the subjectivity of the historian at the centre of the analysis has led to the recognition of the ways in which individual subjectivity shapes history and memory and at the same time is shaped by the collective aspects of history and memory. ${ }^{14}$ Passerini has shown that one way of dealing with the subjectivity of the historian is ego-histoire, a term invented by Pierre Nora in 1987 and rejuvenated recently in a collective endeavour at the European University Institute. ${ }^{15}$ As Passerini explains, this approach involves both the treatment of the historian as an object of historical study, trying to understand the reasons behind her choices for what concerns method and content and the issue of intersubjectivity, which indicates the relationship between generations of historians but also between historians and the protagonists of their studies. ${ }^{16}$

The perspectives of feminist epistemology, especially standpoint theory and Donna Haraway's doctrine and practice of situated knowledges, go beyond the general premise that the historian's values and culture inform the questions posed to the past and that the historian's imagination organises the evidence found in the sources.$^{17}$ They question the assumption that historiography is produced by neutral, impassionate and objective methods. These assumptions identify feminist questions and women's history with the specific, the zealous and the partial, and through this they delegitimise or marginalise feminist historiography. ${ }^{18}$ Feminist epistemology indicates not only that the historian is part of the history s/he produces but also points to the sexist, androcentric and racist assumptions that organise historical writing. Haraway challenges the god-trick of seeing everything from nowhere and insists on the embodied nature of all vision, promoting a doctrine of embodied objectivity, which means situated knowledges. ${ }^{19}$ This vision includes also the possibility of seeing faithfully from another's point of view but also the recognition and theorisation of "subjugated" standpoints. Haraway sets situated and embodied knowledges against various forms of unlocatable, and so irresponsible, knowledge claims.

Feminist historians and standpoint theorists have been critical of viewing the "object" of knowledge as a passive and inert thing. This extends from the conceptualisation of the body and sex as "material-semiotic actors" and embraces the extra-rational, but is discoverable only within inter-subjective relations". ${ }^{21}$ Pas- 
serini argues that "[i]nter-subjective relations become the location for the negotiation of meaning. This approach allows [us] to 'reclaim subjectivity' for those who were classed as 'others' than white middle-class men: black and third world people, working-class people and women."22 Toni Morrison has written extensively on the monology imposed on subjects who were written out of history and the implications of their public representation for the material now available to tell their stories: "One could write about them, but there was never the danger of their 'writing back'. Just as one could speak to them without fear of their 'talking back'. One could even observe them, hold them in prolonged gaze, without encountering the risk of being observed, viewed, or judged in return."23 Moreover, the "monology" imposed by the exclusion of certain memories deprived those excluded of a language with which to narrate their story.

The archive as the male model of the "proper" place where historical research takes place and in which the "proper" sources are located constitutes the standard against which all other evidence must be measured. Historical anthropology has explored the archive both as a physical structure and a repository of ultimate value and has analysed its role in producing the colonised as objects of knowledge..$^{24}$ The ethnography of the archive and the exploration of its form rather than its content show it not as a container of truths but as a signifier of colonial distress and as an epistemological process of temporalisation. ${ }^{25}$

Ann Stoler explores the colonial ontologies of a racial kind that created the foundational fictions of colonial rule. By ontology she means the "ascribed being or essence of things, the categories of things that are thought to exist or can exist in any specific domain and the specific attributes assigned to them". ${ }^{26}$ She researches the epistemic practices that were recorded in colonial archives and which reveal anxieties about what they could have known and how they could have known it. She deals with unsured and hesitant sorts of documentation and the sensibilities that gathered around them.

Feminist scholarship has interrogated both archive and memory as gendered categories and has shown that this gendering has contributed to the marginality of women's and children's experience in and by history. Memory "becomes" her in the sense that is a private realm in which to preserve the past but also in the sense of expressing her relationship to "real" history. ${ }^{27}$ "Memory has been represented as dependent and mendacious (fictional, fickle) and therefore of dubious authority and reliability, all of which are hallmarks of conventional female identity in the context of a heterosexual symbolic economy." ${ }^{28}$ In her inquiry into what constitutes an archive and of the status of memory as evidence, Antoinette Burton demonstrates that "[q]uestioning the verifiability of the evidence produced in sites of memory like oral histories, letters, autobiographies and testimonies throws doubt on the narratives drawn from them as history". ${ }^{29}$ Relegating women's memories to supplements to history is a continuation of the logic of western colonial modernity. The constitution of an archive of memories requires a public affirmation of their status as an archival source.

Notwithstanding the significant influence of feminist history, the domestic continues to be treated as beyond history in modernity. This is attributed to the fact that in national discourses the domestic is considered as timeless and as the universal "other" of modernity and is simultaneously codified as female and private and, consequently, deemed insignificant to be recorded. ${ }^{30}$ 
Burton extends the uses of the word "archive" to include memories of house and home, interrupting in this way the privileging of the archive as some originary site of historical knowledge and evidence. Although the status of women as historical subjects is no longer in doubt, as Burton argues, their capacity to write history is questioned. ${ }^{31}$ The "objective" task of writing history is preserved for men while literature is considered more appropriate for women. Natalie Zemon Davis has challenged the dichotomy between history and literature by exploring the forms of narrative that shape the judicial sources of the past. ${ }^{32}$ As Burton argues, the hierarchical distinction between history and literature is part of the process of the archive becoming part of the quest for a "truth-apparatus" that underlay social science practices. ${ }^{33}$

Influenced by Foucault, feminist historiography recognises the archive as a discursive formation that reflects the categories of the state itself and its panoptical effect. Archiving memory or the domestic and the inclusion of heretofore excluded subjects do not lead to a truer or "historical" history, as Burton argues. The illusion of seeing all subjects effectively submits to a redemptive view of history and reproduces the panoptical presumptions of the traditional discipline..$^{34}$

\section{Challenges to historical narrative}

I will use the work of three historians, Carolyn Steedman, Luisa Passerini and Natalie Zemon Davis, as exemplary of the way in which their historical writing transformed history fundamentally by experimenting in ways of writing history. All three historians cross disciplinary boundaries and push the boundaries of history beyond what they have been. Their work helps us to see how historical consciousness dwells in narrative and its forms. Although I take as examples for my exploration of historical writing Steedman's Landscape for a Good Woman (1986), Passerini's Autobiography of a Generation ([1988] 1996) and Davis' Women on the Margins (1996), my analysis is informed by their other writings as well.

Carolyn Steedman uses the psychoanalytic case study to pose a challenge to the existing historical genres and to problematise the writing of history as well as to relate historical developments to subjective experience. Her book challenges the official interpretative devices of social history and cultural criticisms which had not reckoned with circumstances of exile and condemned envy as a political motive. Yet, although psychoanalysis allows longing, envy and desire to enter the political stories of class exclusion, its form and imagery perpetuate the marginality of those stories that maintain the other's (middle-class) centrality. Furthermore, psychoanalysis does not permit the exploration of social inequality and dispossession in individual subjectivity, something that history can do by allowing subjectivity's entry into political understanding. Steedman's book raises central questions about the development of gender in particular social and class circumstances and challenges conventional accounts of working-class childhood and little girlhood.

Luisa Passerini uses a paradoxical "autobiography of a generation", individual and collective, to explore the intersubjectivity of memory, and the ways in which the individual subject, as the bearer of subjectivity in the psychological, intellectual and cultural sense, is formed by the collective aspects of memory. Using three genres, her own psychoanalysis, the memories of her 
childhood and adulthood as well as her participation in the events of 1968, and the life stories of those who were active participants in 1968, Passerini shows how memory creates a history of itself. Her analysis of interconnected narratives implements a double motion from remembering to analysing the memories of her subjects, the enterprise of mirroring that is effected by her own memories and by the memories of the subjects she has interviewed. It is through this motion that an innovative history of politics is produced.

Natalie Zemon Davis uses the comparative biography and microhistorical narrative to investigate questions of identity in the sixteenth and seventeenth centuries and to extend agency and self-fashioning to a wider range of situations and social groups, women and peasants. Davis enters into a fictitious dialogue between herself and the three women whose lives she seeks to represent. Davis sees history as a performative act, and by emphasising the autobiographical writings of the three women, she engages in a continuing conversation with them. ${ }^{35}$ Through the imaginary dialogue and the historian's questioning by her subjects, we are introduced to an epistemological inquiry of the historian's transferential relationship with the subjects of the past, of her desire for communication, connection and exchange, of incomprehensibility and of her power to pull the strings of the narrative. "Listen to Mistress Proud and Haughty", says Marie de l'Incarnation to Natalie Zemon Davis, ${ }^{36}$ in the same way Steedman, forming an alliance with Samuel Richardson's heroine Pamela, was imaginatively addressed by herself for her defiance: "Who does she think she is?"37

At the same time, we enter into the operation of history, the dual absence that is at the heart of historical affect:

There is history because there is a past and a specific passion for the past. And there is history because there is an absence of things in words, of the denominated in names. The status of history depends on the treatment of this twofold absence of the "thing itself" that is no longer there - that is in the past; and that never was - because it never was such as it was told. Historical affect is bound to the personal absence of what the names name. ${ }^{38}$

But the historian insists on being given another chance, and tells the subjects of the past: "Read it again." ${ }^{39}$

All three historians raise the important issue for the discourse of historical writing of the relation between a politics of knowledge and a poetics of narrative, around the question of the representation of the other. Jacques Rancière argues about a scene crucial for the discourse of historical study that is born with modern revolution: "that of the living person who speaks too much, who speaks incorrectly, out of place and outside speech"..$^{00} \mathrm{He}$ brings the example of Percennius' speech which Tacitus declares null and void by exposing the nonplace of his speech. "Not that Percennius' reasons are declared false... They have, more fundamentally, no relation to the truth. Their illegitimacy is not due to their content but to the simple fact that Percennius is not in the position of legitimate speaker. A man of his rank has no business thinking and expressing his thought." ${ }^{\prime \prime 1}$ The issue for Rancière is that historical writing renders the discourse of illegitimate speakers null and void of meaning, not through exclusion but through a specific suspension of the relations between meaning and truth. It gives them speech in a style that holds together the powers of neutrality and those of suspicion. 
In order for the subjects to be understood and recognised as legitimate speaking subjects, the historian must invent a scene in which spoken words must be audible and individuals may be recognised. Steedman invented this scene by constructing a historical narrative using the psychoanalytic case study as a model. Her aim was to extract the working-class woman's and child's voice from the status that social history had assigned them - as a manifestation of psychological simplicity and as a metaphor for all that has gone wrong in the politics of class. In order to resuscitate their status as subjects, Steedman told the stories of two childhoods, hers and her mother's, located in place and politics, organised around questions of gender and class, to account for forms of class consciousness produced in the child through feelings of envy, longing and desire. This creative activity of invention allows for a redescription and reconfiguration of a common world of experience. It is in this respect that we may speak of a poetics of politics. ${ }^{42}$

All three historians use the biographical and autobiographical mode to illuminate experiences and identities that remained untold and excluded from the narratives of history. At the same time, their historical accounts are of a different order from the biographical because the stories they tell are intersubjective - their individual stories are shaped by the experiences of other people. They used other people's stories of the past to tell their own stories while other people used their stories to reassert their experiences. Thus, a common denominator in all three historians is the understanding of subjectivity as a collective enterprise in which memory and narrative played an important role in its shaping. Steedman uses her own and her mother's childhood in order to tell the secret and marginal stories that other working-class women from a recent historical past have to tell. ${ }^{43}$ As Steedman argues, it is difficult for the historian to think outside the biographical mode, the telling of all stories as if they were a life. The figure of personification gives a name and a face to the subject that is its reference. ${ }^{44}$

This marks a shift in the history of emotional and psychological selfhood which was written by and through the testimony of people in a central relationship to dominant culture. Besides, one of their major contributions lies in the conceptualisation and historicisation of subjectivity. Their approach to memory and to the use of the political, religious and cultural background breaks with the sociological framework which recognises custom and tradition in reshaping individual lives. In approaching subjectivity as the product of cultural production, they recognise the role of imagination and imaginary as Passerini puts it, or the "conceptual and psychological baggage that people carry with them and the disruptions that the irrational and the unconscious make in its running". 45

Passerini introduces the term "shareable" memories in order to show the dynamic dimension of remembering which can be revealed in the process of the reorganisation of past experiences and in the emergence of disputing and conflicting memories. This approach allows the historian to produce alternative versions of the past that would not be possible to extract if she did not take into account the different and conflicting narratives that subjects share and which shape their memory but also the role of silence in the construction of memory. As Passerini argues: "Taking silence into account means to watch out for the links between forms of power and forms of silence - repression of various kinds, censorship. It finally means to look more deeply in those aspects of memory which have to do with oblivion." ${ }^{46}$ 
Davis explores how these women made sense of themselves and with what material they composed the story of an "l". Religion was certainly the stuff that infused their identity as well as family relationships and gender hierarchies. Her biographical account enables the reader to hear the voices of these women, to feel how they felt. Yet, it does not deal solely with identity but also with difference: It explores the relations of these women, imagined or real, with non-European peoples and uses their biographies as the locus where relations of power and claims of superiority emerge. This exploration also allows space for the insertion of non-European eyes that return the Europeans' gaze.

Davis demonstrates that, although these seventeenth-century women' visions and artefacts were created from a marginal place, it is the very fact of their marginality that makes them significant. She perceives the place of the margin as a "borderland between cultural deposits that allowed new growth and surprising hybrids". ${ }^{47}$ These women embraced a marginal place in order to free themselves from the constrictions of European hierarchies. "Women on the margins can reveal with particular clarity what was at stake for women and men both.48

Microhistory offered, in terms of historical method, a new understanding of the experience of the subaltern. While social history was based on a model which organised data in terms of categories developed to permit maximal aggregation (such as wealth, occupation, etc.), microhistory used "names" as markers for the construction of a new type of social history. ${ }^{49}$ The focus on names of ordinary individuals in the past allows their lives to assume the maximum complexity. This complexity arises out of a thick description in which the lived experience of the individual is interpreted through her/his location in a variety of social contexts. ${ }^{50}$ As with the work of Steedman, Davis' microhistorical method aimed at remedying the presentation of subaltern subjectivity as homogeneous and fought against those works that preserved individuality and subjectivity for the elites, as if the subaltern classes did not deserve a history that pays attention to processes of identity formation such as self-fashioning.

Analyzing the workings of memory of the subaltern in sixteenth-century French village life, Davis concludes that individual memory was thought as a personal possession and, as the example of Bertrand de Rols and Arnaud du Tilh shows, their use of memory unfolds an inner definition of the self as well as of social invention of identity. ${ }^{11}$ Self-fashioning is extended to a wider range of situations and social groups to include not only the Renaissance elite but also sixteenth-century peasants. ${ }^{52}$

\section{The historical dynamics of naming ${ }^{53}$}

Extending the critique of the subject to the category "women", Denise Riley designated that "women" is a volatile collectivity while being a woman cannot provide an ontological foundation..$^{54}$ Black and lesbian feminists had pointed to the heterogeneity of women's experience, shaped by differences of race, sexual preference, class and age. Referring to the race and class hierarchies in the middle-class house, Audre Lorde addressed white American feminists and raised 
the issue of the need to theorise the racism of feminism. ${ }^{55} \mathrm{As}$ Joan Scott argued, the history of feminism has participated in producing an essentialised common identity of women as it has been the history of the project of reducing diversities (of class, race, sexuality, ethnicity, politics, religion and socioeconomic status) among females to a common identity of women (usually in opposition to patriarchy, a system of male domination). ${ }^{56}$

For Riley, it is the very identity "women" that has to be questioned, as the specifications of differences still rest on the category "women". "Women" is a historically and discursively constructed category, which became a social category through contested scientific discourses and social practices.$^{57}$ There is nothing about "being" female that naturally binds women while the identity of "women" has been shaped by the different conceptualisations that developed historically.

Riley pointed to the temporality of "women", that is to the impossibility "to live twenty-four hours a day soaked in the immediate awareness of one's sex".58 Any identification with the category of "women" rests, for Riley, on prior positive or negative deployments of the category, positionings and objectifications of women. Thus, there are no innocent ways in which one becomes temporarily woman because it presupposes the adoption of a designation there in advance. An identification that is based on the category of experience emphasising either the distinctiveness of women's bodies or a common experience of subordination is problematic because of the epistemological status both of the category of "experience" and of "women's experience". Women's experience implies that experiences originate with women and in this way it masks that these have accrued to women not by virtue of their womanhood alone, but as traces of domination, whether natural or political. ${ }^{59} \mathrm{Gender}$, race and class identities are the product of the terrible historical experiences of patriarchy, colonialism, racism and capitalism. Experience as a base for identity creates a unitary subject without relativising or interrogating the means of their production..$^{60} \mathrm{As}$ Scott argues, "it is precisely the imposition of a categorical subject-status that has marked the operations of difference in the organisation of social life."61 Describing the differences that separate women can lead to fixed categories, such as working-class, or African-American or Islamic women. Writing their history without asking where the identities come from, when they arise, and what ends they serve, gives these groups a certain eternal being. ${ }^{62}$

Donna Haraway discusses the formation of a new model of political identity called "oppositional consciousness", "born of the skills for reading webs of power by those refused stable membership in the social categories of race, sex, or class". This is a postmodernist identity which breaks with all the signs of Man in western traditions and rests on contradictory locations and heterochronic calendars and not on relativisms or pluralisms. ${ }^{63}$ It creates a coalition through affinity, not identity. Denying any "privileged" oppressed authorial categories such as "woman", "black" and any essential criterion for identifying who is a woman of colour, the definition of "women of colour" has been achieved through a conscious appropriation of negation.

The importance of new modes of writing has been stressed by feminist critique and has come out from the knowledge that "the master's tools will never dismantle the master's house". ${ }^{64}$ The writings of "women of colour" explore the themes of identity of those who "never possessed the original languages, never told the original story, never resided in the harmony of legitimate heterosexuality in the garden of culture".65 
Riley's notion of the volatility and temporality of the category "women" rests on the Lacanian notion of identity formation, according to which becoming a subject involves subjection. At the same time, she follows Foucault's argument that any positioning of the subject by disciplinary discourses produces a contesting politics of the subject. Wendy Brown, although following Foucault's postulation of the subject as an effect of power, discerns an optimism and a kind of volunteerism in him when he assumed that insofar power always produces resistance, the disciplinary subject, capable of resistance, practices freedom. Brown argues that Foucault tacitly assumed the givenness and resilience of a desire for freedom. ${ }^{66}$

Brown proposes the privileging of subject formation over social positioning and argues for an understanding of subjects as not only positioned by power "but as effects of power, as formed or produced by power, and 'as simultaneously undergoing and exercising power"'. ${ }^{77}$ She understands subjects of racial and gender domination as partial effects of regimes and formations of race and sexuality. They construct an oppositional political culture and critique out of their historical exclusion and perform a denaturalising assault on coherent collective identity in the centre. They refuse the invitation to absorption and "insist instead upon politicising and working into cultural critique the very constructions that a liberal humanism increasingly exposed in its tacit operations of racial, sexual, and gender privilege was seeking to bring to a formal close". ${ }^{68}$ Yet, this assault they perform comes back to trouble their own identities.

Brown emphasises the importance of pain in politicised identity and argues that pain is installed at the heart of contemporary demands for political recognition. She argues that politicised identities become attached to their own exclusion because they are premised on this exclusion for their very existence as identity. Simultaneously, the formation of identity "as exclusion augments or 'alters the direction of the suffering' entailed in subordination or marginalization by finding a site of blame for it". In this way, pain becomes the foundation of its political claim and the basis for its demand for recognition as identity. Brown argues that identity structured in part by ressentiment resubjugates itself through its investment in its own pain, through its refusal to make itself in the present.

Brown seeks an exit for this resubjugation and the use of memory as the house of this activity and refusal. She proposes to replace the language of "I am" with the language of "I want" as a way to alter modes of political speech so that it destabilises the formulation of identity as a fixed position, as entrenchment by history, and as having necessary moral entailments. The replacement that Brown proposes of the language of being with that of wanting entails a shift from ontological claims to political ones, claims that forge an alternative future..$^{69}$ Brown's demand for a subject "in motion, as not-I, as deconstructuble according to the genealogy of want rather than as fixed interests or experiences" destabilises presence and reopens the desire for futurity.

Homi Bhabha too shifts the question of identity from the ontological and epistemological imperative What is identity? to the political prerogative What are identities for? to the pragmatist alternative What can identities do? He moves away from a cultural and disciplinary identity to a search for historical locality. Furthermore, his concern for the historical and geographical location of identity rather than the persuasions of personhood moves away from the model of multicultural- 
ism and of the politics of recognition, which is founded, as he argues, on a post-Herderian notion of authenticity. Authenticity is an essential truth understood as a turn or return to ourselves and articulated through a concept of social dialogism. Recognition for Charles Taylor, as Bhabha notices, emanates from a "fusion of horizon" of standards that emerges from an immersion in the culture in question and leads to an understanding of what constitutes worth that was not there at the beginning. The possibility of the "fusion of horizon" of standards constitutes a new standard of judgment and is based on the concept of the dialogic subject of culture. Bhabha criticises the notion of reciprocity on which cultural evaluation and judgment is based. The presumption of dialogical recognition as reciprocity makes the fusing of horizons a homogenising norm of cultural value or worth based on the notion that cultural difference is synchronous. Besides, the process of the transvaluation of cultural judgment presupposes the ahistorical and immanent presence of the dialogical subject of authenticity. More problematic is the totalising effect that the notion of dialogic recognition has on cultural difference. As Bhabha argues, "reciprocity assumes that dialogic recognition exists within a binary relationship that consists of two unitary (individual or collective) cultural subjects; difference is constituted and totalised within each culture."70

Bhabha adopts the problematic of proximity for the production of the minority subject rather than the question of reciprocity. He replaces the "relation of the two" with the internally ambivalent subject structured through the temporal disjunction of present being. Dialogism demands temporal coevality for successful recognition, but the minority subject emerges from a history of discriminatory and exclusionary practices. The minority subject is produced through the proximity of difference. ${ }^{71}$ In Taylor's conceptualisation of migrant or diasporic peoples, Bhabha reads the model of a national peoples, as representatives of their national or atavistic cultural heritages, or as part of a mosaic within the homogeneous empty time of the nation. Bhabha formulates difference as a proximate activity in the sense of the ambivalence in identification with others, objects, ideas, ourselves. The difference of proximity refuses to posit the relations of persons or cultures as different on the normalising grounds of an abstract universality of meaning or on a shared, synchoronised temporality of present being. Proximity is the excess of the hybrid state, where the problem for the American black and white person is neither incorporation nor assimilation but the recognition of the double relation and its "interfection". The poetics of proximity, that is writing in the middle of difference, is a political movement.

Jacques Rancière's elaboration of political subjectivisation connects his historiographical practice with politics calling for a transformation of the poetic structures of knowledge. For Rancière, the identification of politics with the self of a community is what constitutes the dead end of political reflection. It can be articulated through the claim of identity for the so-called minorities against the hegemonic role of the ruling culture and identity. Or it can be expressed through the identification of governing with the principle of the community under the axiom of universality, the law or liberal democracy. Although they are not equivalent practices, they stem from the same questionable identification. Policy acts as the self of the community and turns the techniques of governing into natural laws of the social order. Rancière distinguishes policy from politics and through this distinction he formulates the politics of emancipation as the politics of the self as an other. The logic of emancipation is a heterology..$^{72}$ The process of emancipation is enacted in the name of a category denied either the principle or the consequences of that equality: 
workers, women, people of colour or others. It is not enacted in the name of a social category with which the subject that invokes its rights could identify with. Because it is the name of an outcast. Outcast is the name of those who are denied an identity in a given order of policy. Thus, the process of subjectivisation is a process of disidentification or declassification. It is the name given to people who are in-between: between humanity and inhumanity, citizenship and its denial, between the status of a man of tools and the status of a speaking and thinking being. The place for the working out of difference is an interval or a gap: being together to the extent that we are in-between, between names, cultures, identities. "Policy is about 'right' names, names that pin people down to their place and work. Politics is about 'wrong' names - misnomers that articulate a gap and connect with a wrong."73 Political subjectivisation is not about the settlement of a wrong, consensus or innocent communication but the handling of a wrong by people who are together to the extent that they are in-between. ${ }^{74}$

Rancière departs from the communicative rationality mode that presupposes the existence of a priori pragmatic constraints that compel interlocutors to communicate and, thus, rests on the premise that both speaker and the objects about which they speak are preconstituted. The historiographical practice Rancière introduces is concerned with the liberation of the discourse of subaltern subjects from the dictates of historicism, which is a discourse of propriety, of keeping things "in their place". ${ }^{75}$ Rancière deals with the "excess of words", with the power of subjects to circulate words, "useless" and unnecessary words that exceed the function of rigid designation. Workers were able to use and reappropriate abandoned terms such as tyrant, proletarian, and in this way they designated a category of political subjectivity. They reconfigured the relation between the visible and the sayable, the relation between those who are entitled to speak and those who are not. This act signifies a "partition of the sensible", that is, of what it was possible to say. For Rancière, "politics is an activity of reconfiguration of that which is given in the sensible." ${ }^{76}$ At the same time, the historian needs a poetics of knowledge in order to account for subaltern subjects as legitimate speaking subjects. This means redeeming the workers' speech from the status cultural and social history assigned to them and treat them as inventions of forms of language similar to all others. A new poetics of knowledge is indifferent to the status of the speaker but also presents a challenge to the divisions between the disciplines and the discourses of knowledge. ${ }^{77}$

Rancière departs from a conception of history that explains things only in terms of their specific time and place, which involves a notion of contemporaneity established particularly by the history of mentalities. He opposes this notion, according to which one can only think what a specific time and place allows us to think. "To explicate a phenomenon by referring it to its time," Rancière argues, "means to put into play a metaphysical principle of authority camouflaged as a methodological precept of historical inquiry". ${ }^{78}$ His notion of contemporaneity presupposes the restaging of certain entirely anachronistic, symbolic oppositions in workers' utterances, like those found in the etymology of proletarius. The historian has to designate those instances when one authorises oneself to think what that particular time considered illegitimate to think. 


\section{History of science, history of the body and history of sexuality}

Fields that had been considered marginal in the historical discipline, such as the history of science, the history of the body and the history of sexuality, challenged the positivist model; introduced to historiography new theoretical and methodological tools and new kinds of sources such as anatomical maps, medical records, wax models; exercised an epistemological critique to traditional sources and broke disciplinary boundaries. Furthermore, they incited historians to rethink the nature of categories like selfhood, identity and modernity.

Among of the aims of researchers in these fields were to explore the extent to and the ways in which gender informs historical practice and the extent to which notions of femininity and masculinity inform the production of scientific knowledge, what we see and how we see it. The analysis of the metaphors that science used revealed that they were defined by the dichotomies of male-female, nature-culture, active-passive, public-private, which all referred immediately to sexual difference. ${ }^{79}$ The eighteenth-century wax models of the female body and the images of anatomy showed the construction of the female body as a passive object of historical research discovered by the scientist. ${ }^{80}$

These fields of history do not focus on events, mentalities or problems but to the processes through which science constituted itself as a regime of truth. The shift in epistemological paradigms is one of the ways to understand ruptures, changes and discontinuities. Thomas Laqueur argues that the one-sex model dominated thinking about sexual difference from late antiquity to the seventeenth century. ${ }^{81}$ While prior to 1700 , male and female bodies were seen as homologous, in the eighteenth century they started to be perceived by anatomists as fundamentally distinct. The two-sex model, as Laqueur argues, was not the outcome of scientific advances but of political considerations that required new justifications for gender inequality and masculine dominance. The new model was not the result of scientific observation but was created in political discourse within the framework of the contest for power and middle-class domination. ${ }^{82}$

Most historians consider the eighteenth century as a key stage in the development of categories of male and female as incommensurable biological sexes. Laqueur's work has been criticised for assuming the universality of a one-sex model in the early modern period and for ignoring other sources that revealed nonprofessional understandings of conception and sexual difference, such as pornography, cheap medical treatises and court depositions ${ }^{83}$ Karen Harvey attempted to reconstruct other ways the body was understood by reading eighteenth-century erotica as a guide to conceptions of the sexed body. ${ }^{84}$ Furthermore, historians do not assume a smooth transition from the one-sex to the two-sex model and have observed the coexistence of the two models both during Reformation and at the end of the nineteenth century, taking Freud as an example. Randolf Trumbach argues for a shift from the existence of three kinds of bodies and two genders prior to 1700 to the existence of two kinds of bodies and three genders after $1700 .{ }^{85}$ In recent work, Laqueur's thesis of a move from a one-sex to a two-sex model of bodies is integrated into a much broader picture incorporating both sexual desire and gender roles. ${ }^{86}$

Gianna Pomata has called into question the primacy of the male body as the Gestalt, the paradigm that guided the perception of the female body in medical discourse from antiquity to the 
late eighteenth century. Taking as an example haemorrhoidal bleeding, which was perceived as menstrual flow, she argues that in early modern European medicine it was the female body that was exemplary from a therapeutic point of view while the male body emulated the menstruating female body ${ }^{87}$

Historians of the body and sexuality have seen it as their task to take a second look at apparent truths and as a central aim of their exploration into how modern certainties came into being. ${ }^{88}$ Carolyn Walker Bynum showed that the body has a history and that the female body in particular started to behave differently between the thirteenth and fifteenth centuries in Europe. ${ }^{89}$ Placing the female body at the centre of her analysis, Bynum argued that the somatisation of religious experience observed in the thirteenth century constitutes a particularly female expression of religious experience and signifies a new conception of the individual as a psychosomatic unity. The association of women with the body or the humanity of Christ in theological doctrines led to an identification of Christ's flesh with the female, at least in its therapeutic functions and nurturing. If we look at the traditions (physiological theory, theology, medicine) that associated women with matter, flesh and food, we will not find the medieval dichotomies of psyche and body. Medieval theologians and natural philosophers, Bynum argues, "often mixed and fused the genders, treating not just the body of Christ but all bodies as male and female". 90 The religious iconography that represented Christ's body both as female and as male shows the permeability of genders in medieval thinking. Thus, the conception of the body was much more complex than the dichotomic view that identified the female body with sin and the male with spirituality.

The meeting of gender history with social anthropology destabilised the primacy of the event in the study of the past as well as conventional modes of periodisation by placing emphasis on ruptures rather than continuities. ${ }^{91}$ The study of sexual violence and crimes of honour through the analysis of symbolic representations and cultural scripts that circumscribe the arena within which past experiences make sense highlighted the historicity of concepts like honour and sexuality, their cultural meanings and their role in defining gender and class relations. ${ }^{92}$ The examination of persecutions for superstitious and magical practices in the Venetian Inquisition in the sixteenth and seventeenth centuries shows that gender identity and conceptions of honour constituted fields of negotiation within the framework of the disciplining of the population. ${ }^{93}$ The understanding of the past as "other", the exploration of alien perspectives of the past and the call on the historian to see the past through the native's interpretation of the ways in which natives feel and think are invitations to shake off feelings of familiarity with the past and to deal with doses of cultural shock. Yet, the acceptance of a radical alterity of the past belies a homogeneous understanding of the past and reveals the difficulty of the historian to discern the "projection" onto the other and her transferential relation to the past. ${ }^{94}$

The use of psychoanalytic concepts in the study of conflicts that arose around issues of sexuality and gender, religion and witchcraft has offered innovative analyses of the ways subjects experienced various forms of violence in the past. Miranda Chaytor studied rape accusations in seventeenth-century England and used a psychoanalytically informed approach on memory. Understanding memory as a process of exclusion as well as inclusion, Chaytor looks for the thoughts that the narratives of rape refused to accommodate, which were resisted within them 
and displaced. This reading of the unconscious in the narratives is a psychoanalysis that can be put to historical use because it looks outwards to the culture from which the thoughts in question have come. ${ }^{95}$ In the husband(ry) framework, narratives tried to keep the sexual at bay. Honour in rape accusations lay not in the victim herself but above and beyond her - in belonging, in her husband(ry). What the women and children refused to remember was the rape itself, the sexuality of it, the body penetrated, dirtied, bleeding, in pain. What they put in sexuality's place was a property crime.

Barbara Duden moved from the "history of the body" to the "history beneath the skin", that is to the histories of perceptions that penetrate the skin. She proceeded from an understanding of the body "as an epoch-specific experience" to a "historical somatology", that is, to the research on the somatic referent of the grammatical "first person singular": the flesh and blood, the substance of the speaking "I". Studying how women in the eighteenth century experienced their bodies, Duden observed that they did not talk about their body but about themselves. Their narratives were a "bio-logy", that is logos (discourse) about vios (life), and by this she understood that the first person has a history. She understands the body as the ultimate stuff, as something that cannot be abstracted (the concretissimum), and in consequence as something that can only be understood by mimesis, in the ancient meaning of the word. By mimesis Duden means her attempt as a historian to estrange from herself, of the way she feels her body which is the result and condition of her historical somatology. Duden is not interested in creating a "body" of historical evidence of body history but in learning how to embody the pastness of "biology" in her own present, which demanded the cultivation of haptic mimesis, the refinement of her sensorium, and the survival of her synaisthisis (common sense). In other words, to create a historical method based on "a gut feelings for the past". 96

In order to trace the historicity of somatic autoception - the different ways people sensed their bodies in different historical periods - she focuses on pregnancy as a privileged instance in which to grasp the contrast between becoming pregnant and diagnosed pregnancy. As a historian of the unborn, Duden argues that "life" was a nonexistent technical concept except at the beginning of the nineteenth century and it is nowadays used only in conversation and not in science. She perceives the recent coinage of "life" as an indication of a huge epistemological break. Duden asks for a questioning of the certainties that led women in a corner "where pregnancy is defined in terms of the modern fetus and then in terms of something called life, for which we are all asked to take public responsibility". ${ }^{97}$

Duden explores "the conditions under which, in the course of one generation, technology along with a new discourse has transformed pregnancy into a process to be managed, the expected child into a fetus, the mother into an ecosystem, the unborn into a life, and life into a supreme value". ${ }^{98}$ The main objective of her study is to show that the human foetus is an engineered construct of modern society whose invention and acceptance led not only to the disembodiment of women but also to her subjection to the professional management of her "scientifically" defined needs.

Duden examines how the woman was constructed as a scientific fact, the foundations of which were laid in the eighteenth century. How did this fact become so popular and how was it inter- 
nalised by women like herself and also projected onto women in the past? What circumstances made the skinning of women acceptable and inspired public concern for what happens in her innards? What made possible the massive mobilisation of women in becoming accomplices in the opening of their flesh, and in witnessing the creation of this symbol of loneliness, of the foetus? She was led to these questions when she understood that the women patients in the eighteenth century experienced their bodies differently than her. ${ }^{99}$ The disembodiment of the I, which introduces the body into the canon of historical subjects, is an obstacle for the modern historian in understanding the somatic-autoception of women in the past and the somatic mimesis through which the eighteenth-century doctor embodied the tragedy of the human condition.

The history of the body and the history of sexuality have become established fields of inquiry that explore the interrelationship between forms of selfhood and modernity. ${ }^{100}$ Furthermore, the emergence of the historicity of sexuality and sexual practices as a central preoccupation of feminist history and queer studies has caused trouble in historiography in respect to notions of familiarity, periodisation and of the past as a source of identity. Into the centre of the historiographical debate came the question of the modern notion of sexual identity and whether there was such an identity before the nineteenth century. ${ }^{101}$ Eve Kosofsky Sedgwick offered an escape from this impasse by arguing that it is not right to assume a smooth transition of identities in chronological sequence. The inquiry of how modern the modern homosexual is aimed at redeeming queer material from the condensation of medieval historiography but also to show similarities between the medieval and postmodern homosexual. ${ }^{102}$ The ultimate aim was to challenge conventional notions of periodisation of western epistemology and to bring forth the heterosexual projection of historians to the past.

Feminist historians have emphasised the management of sexuality as a central factor of colonial ideology and practice in determining political and administrative procedures of colonial government. Philippa Levine has indicated the establishment of a census-style knowledge in British colonies in the nineteenth century whereby a sex census was fashioned by counting, enumerating and categorising women who worked in prostitution. ${ }^{103}$ Paul Kramer showed the politicisation of prostitution during the Philippine-American War and the emergence of systems of regulation that issued gendered and racialised notions of morality and disease. ${ }^{104}$ Historians of sexuality and researchers of queer studies promote alternative practices of reading the past, emphasising the presence of the past in the present and proposing a "phasmatic historiography", 105 a systematic investigation of what is hidden and unseeable, of what is below or behind the phenomena that manifest the existence of a past. ${ }^{106}$ They challenge conventional concepts of periodisation and provoke a rethinking of the gender prejudices of epistemological foundations. ${ }^{107}$

The concept of gender brings into critical examination the foundational principles of historiography, the premises of its existence. As Sarah Mahler points out, we have to look for gender not only in the right places, in which we expect to find women, or in the places where women ceremonially inhabit but also in the wrong places, where women are absent. ${ }^{108}$ As gender organises relations of power in different fields, Mahler calls for an examination of gendered geographies of power such as international frameworks, world-systems and migration. Similarly, Eleni Varikas perceives gender history as history against the grain. We should not seek, she ar- 
gues, the subjects in their place, where a preconstituted and normative perception of "society" puts them: the worker in the factory, the domesticated woman in the house, black people in the plantation, minorities in the ghetto. Following Theodor Adorno's argument that objectification is a kind of oblivion, Varikas suggests that we have to rethink and unearth what is hidden beneath the taken-for-granted of a procedure, of a theory, of a concept - in the sense of what has been repressed or suppressed. "The research of the historicity of gender is rooted in the remembering of all that has been neglected, forgotten or thought as resolved within the framework of the logic of finished events." ${ }^{109}$

Feminist critique proposes the shift from the discussion of identity from the perspective of personality - be it individual, collective, subordinate or dominant - to its handling as an issue of historical and geographical location. This location is perceived as part of the production of the subject, as a component of its shaping. The turn towards world history and the insertion of gender into it open new ways of understanding how gender and race produce hierarchies and sustain colonial domination; they also remove historiography from Eurocentric dichotomic approaches and reifications of the nation by focusing on interrelation, communication, contact and exchange. 


\section{NOTES}

1 Alun Munslow, The New History, Pearson Longman: London, 2003, 2.

2 Jacques Rancière, The Names of History: On the Poetics of Knowledge, trans. Haasan Melehy, Minneapolis: University of Minnesota Press, 1994, 7.

3 For historicism's conception of time and the critique of subaltern studies, see Dipesh Chakrabarty, Provincializing Europe: Postcolonial Thought and Historical Difference, Princeton: Princeton UP, 2000, 23. For reflections on gender and periodisation, see Julia Hardwick, "Did Gender have a Renaissance? Exclusions and Traditions in Early Modern Western Europe", in Teresa Meade and Merry Wiesner-Hanks (eds), A Companion to Gender History, Oxford: Blackwell, 2004, 343-57; also Alexandra Shepard and Garthine Walker, “Gender, Change and Periodisation”, Gender and History 20:3 (2008): 453-62.

4 Munslow, The New History, 15-17, 181; Georg Iggers, Historiography in the Twentieth Century: From Scientific Objectivity to the Postmodernist Challenge, Middletown: Wesleyan UP, 1995. For the structural

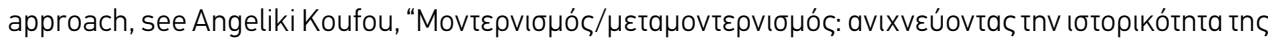

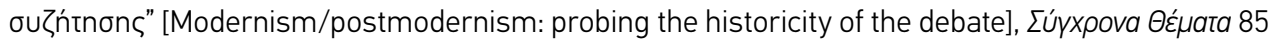
(2004): 84-99 (96).

5 For the understanding of historiography as epistemological inquiry, see Paul Ricoer, Memory, History, Forgetting, trans. Kathleen Blamey and David Pellauer, Chicago: University of Chicago Press, 2004, 136-38.

6 Joan Scott, “Feminism's History”, Journal of Women's History 16:2 (2004): 10-29 (19).

7 Ibid., 10.

8 Bonnie Smith, The Gender of History: Men, Women, and Historical Practice, Harvard: Harvard UP, 1998; Joan Scott, "American Women Historians, 1884-1984", in Gender and the Politics of History, New York: Columbia UP, 1999, 178-98; Luisa Passerini and Polymeris Voglis (eds), Gender in the Production of History, Badia Fiesolana: European University Institute, 1999.

9 Regina Schulte, "The Queen - A Middle-Class Tragedy: The Writing of History and the Creation of Myths in Nineteenth-Century France and Germany", Gender and History 14:2 (2000): 266-93.

10 Luisa Passerini, "Shareable Narratives? Intersubjectivity, Life Stories and Reinterpreting the Past", Advanced Oral History Summer Institute, 11-16 August 2002, Berkeley. Quoted here with the permission of the author.

11 Bonnie Smith, "Gender and the Practices of Scientific History: The Seminar and Archival Research in the Nineteenth Century", American Historical Review 100 (1995): 1150-76 (1150).

12 Ibid., 1153, 1158

13 Passerini and Voglis, Gender in the Production of History, iv.

14 Passerini, "Shareable Narratives?"

15 Luisa Passerini and Alexander Geppert (eds), “European Ego-Histoire: Historiography and the Self”, Historein 3 (2001).

16 Passerini. "Shareable Narratives?" 3.

17 Donna Haraway, “Situated Knowledges", in Simians, Cyborgs, and Women: The Reinvention of Nature, London: Free Association Books, 1991, 183-200. Also, Linda Nicholson, "Introduction”, in Linda Ni- 
cholson (ed.), Feminism/Postmodernism, London: Routledge, 1989, 3. About Collinwood's "webs of imagination", see Munslow, The New History, 146.

18 Sandra Harding, “Feminism, Science, and the Anti-Enlightenment Critiques", in Nicholson (ed.), Feminism/Postmodernism, 87.

19 Haraway, “Situated Knowledges”, 188.

20 Ibid., 200.

21 Hollway, quoted in Passerini, "Shareable Narratives?", 3.

22 Ibid., 4.

23 Toni Morrison, “Unspeakable Things Unspoken: The Afro-American Presence in American Literature", in Terry Lovell (ed.), Feminist Cultural Studies, vol. 2, Aldershot: Elgar, 1995, 491.

24 Nicholas Dirks, "Annals of the Archive: Ethnographic Notes on the Sources of History", in Brian Keith Axel, From the Margins: Historical Anthropology and its Futures, Durham: Duke UP, 2002, 47-65; Benedict Anderson, Imagined Communities: Reflections on the Origins and Spread of Nationalism, chap. 10, “Census, Map, Museum”, London: Verso, 2006; Ann Stoler, Along the Archival Grain: Epistemic Anxieties and Colonial Common Sense, Princeton: Princeton UP, 2009. For an ethnographic history of personal archives, local historians and innovative reflections on the politics of the production of history from the margins, see Penelope Papailias, Genres of Recollection: Archival Poetics and Modern Greece, New York: Palgrave Macmillan, 2005.

25 Brian Axel, "Introduction: Historical Anthropology and its Vicissitudes", in Axel, From the Margins, 21

26 Ann Stoler, Along the Archival Grain: Epistemic Anxieties and Colonial Common Sense, Princeton: Princeton UP, 2008, 4.

27 Antoinette Burton, Dwelling in the Archive: Women Writing House, Home and History in Late Colonial India, Oxford: Oxford UP, 2003, 25.

28 Ibid., 21.

29 Ibid., 23.

30 Ibid., 19-20. See also Partha Chaterjee, The Nation and Its Fragments: Colonial and Postcolonial Histories, Princeton: Princeton UP, 1993.

31 Burton, Dwelling in the Archive, 20.

32 Natalie Zemon Davis, Fiction in the Archives: Pardon Tales and their Tellers in Sixteenth-Century France, Stanford: Stanford UP, 1987. Davis examines the relationship between fiction, history and truth in the pardon letters of sixteenth-century France. For an account of the experience of the archive as an entry to the epistemology of historical knowledge, see Arlette Farge, Le goût de l'archive, Paris: Seuil, 1997.

33 Burton, Dwelling in the Archive, 20.

34 Ibid., 143.

35 See Munslow, The New History, 13.

36 Natalie Zemon Davies, Women on the Margins: Three Seventeenth-Century Lives, Harvard: Harvard UP, 1996, 4.

37 Carolyn Steedman, Past Tenses: Essays on Writing, Autobiography and History, London: Rivers Oram 
Press, 1992, 8-9.

38 Rancière, The Names of History, 63. See also Steedman's point about the "double nothingness" in the writing of history and in the analysis of it, which is related to the nineteenth-century perception of childhood as a timespan and the use of the child as a metonymy for history, for what was there once and then lost. "The search for the historian's nostalgia for origins and original referents cannot be performed, because there is actually nothing there: she is not looking for anything: only silence, the space shaped by what once was; and now is no more;" Dust: The Archive and Cultural History, Manchester: Manchester UP, 2001, 154. Also Strange Dislocations: Childhood and the Idea of Human Interiority, 1780-1930, London: Virago, 1995.

39 Zemon Davies, Women on the Margins, 4. Antonis Liakos theorises this dialogue as an illustration of paradigmatic history in which "subjects are not simply vehicles of meaning; they have also an active role in imposing meanings. This is why the tales that are often employed take the form of social drama." "The Transformation of Historical Writing from Syntagmatic to Paradigmatic Syntax", Historein 2 (2000): 47-54 (52). Steedman in her recent book on domestic servants in England in the eighteenth century refers to historians' accounts of class formation as drama. Her book is an attempt to insert domestic servants into this drama of class formation; Master and Servant: Love and Labour in the English Industrial Age, Cambridge: Cambridge UP, 2007, 25-26.

40 Rancière, The Names of History, 24.

41 Ibid., 26.

42 Jacques Rancière and Davide Panagia, "Dissenting Words: A Conversation with Jacques Rancière", Diacritics 30:2 (2000): 113-126 (116).

43 Carolyn Steedman, Landscape for a Good Woman, London: Virago, 1986, 5.

44 Steedman, Dust, 149. See also Goeff Eleys' discussion on the exploration of modern subjectivity in relation to various forms of writing in Steedman's work; Goeff Eley, A Crooked Line: From Cultural History to the History of Society, Ann Arbor: University of Michigan, 1995, 177-79.

45 Steedman, Landscape for a Good Woman, 102.

46 Passerini, “Shareable Narratives", 7.

47 Davis, Women on the Margins, 210.

48 Ibid., 211.

49 Jacques Revel elaborated these points in "Microanalysis and the Construction of the Social", trans. Arthur Goldhammer, in Jacques Revel and Lynn Hunt, Histories: French Constructions of the Past, New York: New Press, 1995, 492-502.

50 "Here, the individual is not conceptualised as antithetical to the social: the hope was to achieve a new angle of vision by following thread of a particular destiny - that of a man or group of men - and with it the multiplicity of spaces and times, the complex tangle of relations in which that destiny became involved"; Revel, "Mircoanalysis and the Construction of the Social", 498.

51 Natalie Zemon Davis, “On the Lame”, American Historical Review 93:3 (1988): 572-603 (602).

52 Ibid., 590.

53 I take this title from lan Hacking's book Historical Ontology, which deals with how novel entities came 


\section{Gender History and the Transformation of the Poetics of Historical Knowledge}

into being and "how the practices of naming interact with the things we name". lan Hacking, Historical Ontology, Harvard: Harvard UP, 2002, 2, 26.

54 Denise Riley, Am I That Name? Feminism and the Category of "Women" in History, London: Macmillan, 1988, 2.

55 Audre Lorde, Sister Outsider: Essays and Speeches, Trumansburg: Crossing Press, 1984, 112.

56 Joan Scott, "Introduction", in Joan Scott (ed.), Feminism and History, Oxford: Oxford UP, 1996, 3.

57 Donna Haraway, "A Manifesto for Cyborgs: Science, Technology, and Social Feminism in the 1980s", in Nicholson (ed.), Feminism/Postmodernism, 190-233 (197).

58 Riley, Am I That Name? 96.

59 Ibid., 101.

60 Joan Scott, “The Evidence of Experience”, Critical Inquiry 17:4 (1991): 773-97 (791).

61 Ibid., 792.

62 Joan Scott, "Introduction", 7.

63 Barbara Smith (ed.), Home Girls: A Black Feminist Anthology, New York: Kitchen Table Press, 1983. Trinh T. Minh-ha, Women, Native, Other, Bloomington: Indiana UP, 1989. See Haraway, "A Manifesto for Cyborgs", 197.

64 Lorde, Sister Outsider, 112.

65 Haraway, "A Manifesto for Cyborgs", 217.

66 Wendy Brown, States of Injury: Power and Freedom in Late Modernity, Princeton: Princeton UP, 1995, 64.

67 Ibid., 119.

68 Ibid., 53.

69 Ibid., 76.

70 Homi Bhabha, “Editor's Introduction: Minority Maneuvers and Unsettled Negotiations”, Critical Inquiry 23:3 (1997): 431-59 (450).

71 lbid.

72 Jacques Rancière, "Politics, Identification, Subjectivization", in John Rajchman (ed.), The Identity in Question, New York: Routledge, 1995, 63-72 (64-65).

73 Ibid., 67.

74 Ibid., 66-7.

75 Similarly, Antonis Liakos introduces a "poetics of history" according to which history is perceived as a complex communicative process in which historical meaning depends on hermeneutic frameworks.

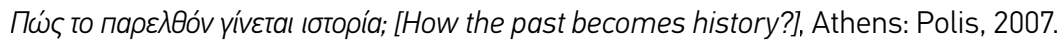

76 Rancière and Panagia, “Dissenting Words”, 115.

77 Ibid., 116.

78 Ibid., 122.

79 Emily Martin, "The Egg and the Sperm: How Science Has Constructed a Romance Based on Stere- 
otypical Male-Female Roles", Signs 16:3 (1991): 485-501. Evelyn Fox Keller, Secrets of Life, Secrets of Death: Essays on Language, Gender and Science, New York: Routledge, 1992.

80 Ludmilla Jordanova, Sexual Visions: Images of Gender in Science and Medicine between the Eighteenth and Twentieth Centuries, Hemel Hempstead: Harvester Wheatsheaf, 1989.

81 Thomas Laqueur, Making Sex: Body and Gender from the Greeks to Freud, Cambridge: Cambridge UP,

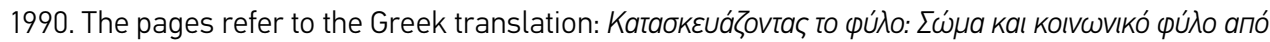

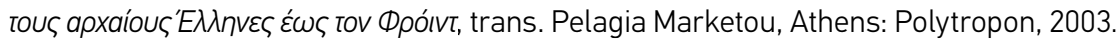

82 Ibid., 211-13.

83 See H.G. Cocks, "Modernity and the Self in the History of Sexuality", Historical Journal 49:4 (2006): 1211-27.

84 Karen Harvey, "The Substance of Sexual Difference: Change and Persistence in Representations of the Body in Eighteenth-Century England", Gender and History 14 (2002): 202-23.

85 See Karen Harvey, "The Century of Sex? Gender, Bodies, and Sexuality in the Long Eighteenth Century", Historical Journal 45:4 (2002): 899-916 (904-906). For a discussion on the epistemology of enu-

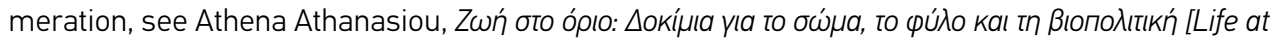
the limit: essays on the body, gender and biopolitics], Athens: Ekkremes, 2007, 212-16.

86 Ibid., 905.

87 Gianna Pomata, “Uomini mestruanti: Somiglianza e differenza fra i sessi in Europa in età moderna”, Quaderni storici 79 (1992): 51-103.

88 Barbara Duden, Disembodying Women: Perspectives on Pregnancy and the Unborn, trans. Lee Hoinacki, Harvard: Harvard UP, 1993, 5.

89 Caroline Walker Bynum, Fragmentation and Redemption: Essays on Gender and the Human Body in Medieval Religion, New York: Zone Books, 1992.

90 Ibid., 185.

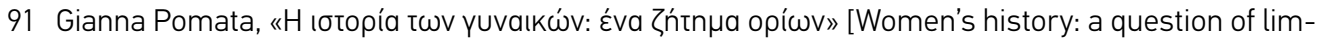

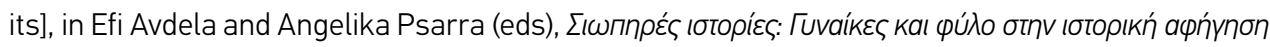
[Silent stories: Women and gender in the historical narrative], Athens: Alexandria, 1997, 149-229.

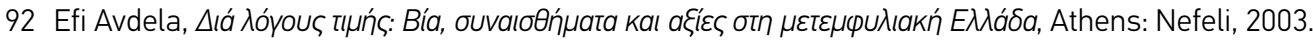
Judith Walkowitz, City of Dreadful Delight: Narratives of Sexual Danger in Late-Victorian London, London: Virago, 1992. Thomas Gallant, Experiencing Dominion: Culture, Identity, and Power in the British Mediterranean, Notre Dame: University of Notre Dame Press, 2002.

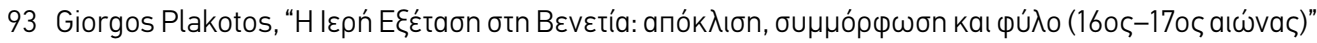
[Deviance, conformity and gender in the Venetian inquisition (16th-17th centuries)], Ta lotopıká/Historica 46 (2007): 89-127.

94 Rika Benveniste elaborates Dominique LaCapra's use of transference as an important component

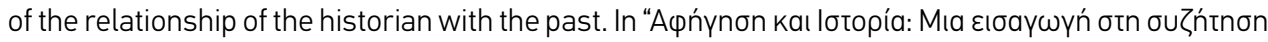

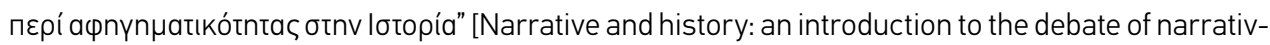

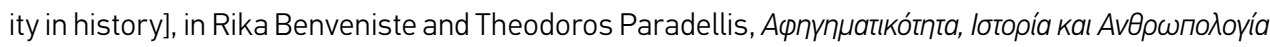
[Narrativity, history and anthropology], Mytilini: University of the Aegean, 1994, 1-24 (14).

95 Miranda Chaytor, "Husband(ry): Narratives of Rape in the Seventeenth Century", Gender and History 


\section{Gender History and the Transformation of the Poetics of Historical Knowledge}

7:3 (1995): 378-407 (394).

96 Barbara Duden, "A Historian's 'Biology': On the Traces of the Body in a Technogenic World", Historein 3 (2001): 89-102 (90).

97 Duden, Disembodying Women, 4.

98 Ibid., 2.

99 Ibid., 5.

100 Cocks, "Modernity and the Self in the History of Sexuality", 1211.

101 lbid., 1212-14.

102 See Dan Healy, "(Homo)sex in the City Only? Finding Continuity and Change in the Gay Past", Gender and History 16:1 (2004): 198-204.

103 Philippa Levine, Prostitution, Race, and Politics: Policing Venereal Disease in the British Empire, New York: Routledge, 2003, 199-213.

104 Paul Kramer, "The Darkness That Enters the Home: The Politics of Prostitution during the Philippine-American War", in Ann Laura Stoler (ed.), Haunted by Empire: Geographies of Intimacy in North American History, Durham: Duke UP, 2006, 366-404.

105 Carla Freccero, Queer/Early/Modern, Durham: Duke UP, 2005.

106 This is Hayden White's interpretation of Rancière's elaboration of a scientific study of the past, "Forward: Rancière's Revisionism", in Rancière, The Names of History, viii.

107 Glenn Burger and Steven Kruger (eds), Queering the Middle Ages, Minneapolis: University of Minnesota Press, 2001. Stephen Murray, Homosexualities, Chicago: University of Chicago Press, 2000. Ko-

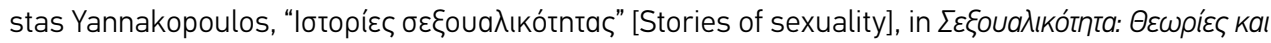

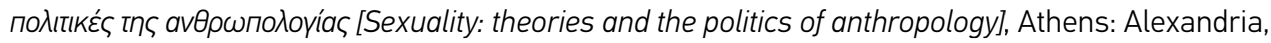
2006.

108 Sarah Mahler, "Looking at Gender in all the Wrong Places - Too". Conference on Migration and Domestic Work in Global Perspective. The Netherlands Institute for Advanced Studies, Wassenaar, 26-29 May 2005.

109 Eleni Varikas, Penser le sexe et le genre, Paris: Presses Universitaires de France, 2006. Pages refer

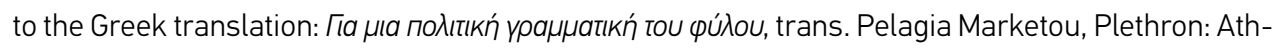
ens, 2008, 83-86. See Efi Avdela and Angelika Psarra's article on the Greco-Turkish War of 1897 as a unique case to understand the articulation between nationalism, war, gender and class: "Engendering 'Greekness': Women's Emancipation and Irredentist Politics in Nineteenth-Century Greece", Mediterranean Historical Review 20:1 (2005): 67-79. 